\title{
Article
}

\section{Developing Employment Opportunities for Care Leavers}

\author{
Bilson, Andy, Price, Joanna and Stanley, Nicky
}

Available at http://clok.uclan.ac.uk/6931/

Bilson, Andy, Price, Joanna and Stanley, Nicky ORCID: 0000-0002-7644-1625

(2010) Developing Employment Opportunities for Care Leavers. Children \& Society, 25 (5). pp. 382-393. ISSN 09510605

It is advisable to refer to the publisher's version if you intend to cite from the work. http://dx.doi.org/10.1111/j.1099-0860.2009.00287.x

For more information about UCLan's research in this area go to

http://www.uclan.ac.uk/researchgroups/ and search for <name of research Group>.

For information about Research generally at UCLan please go to http://www.uclan.ac.uk/research/

All outputs in CLoK are protected by Intellectual Property Rights law, including Copyright law. Copyright, IPR and Moral Rights for the works on this site are retained by the individual authors and/or other copyright owners. Terms and conditions for use of this material are defined in the policies page.

\section{CLoK}

Central Lancashire online Knowledge www.clok.uclan.ac.uk

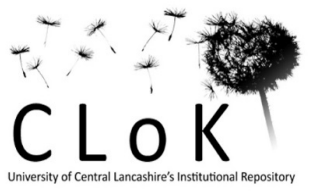




\section{Developing Employment Opportunities for Care Leavers.}

\section{Background}

For most young people gaining employment is a key stage in their transition to adulthood. The Government White Paper "New Opportunities: Fair Chances for the Future" (HM Government 2009) makes a commitment to provide apprenticeships for "all suitably qualified care-leavers up to the age of 25" (HM Government, 2009 p. 10). It is difficult to assess accurately the number of children who might be covered by the Government's promise. According to data from national statistics, in England alone there are around 59,000 young people who left care aged 16 and over between 2000 and 2008 and who would have been aged under 25 on $31^{\text {st }}$ March 2008. There are no figures for the current educational attainment of this cohort or the number of them that will be unemployed or in casual or temporary employment. However, the statistics (DCFS, 2008; DFES, 2003) suggest that around 94 per cent (over 55,000) of them did not have five GCSEs or more at $A *$ to $C$ when they left care, whilst 59 per cent (over 34,000) did not have even one GCSE or NVQ. The White Paper points to an increase in care leavers staying on in education and the figures for care leavers at 19 years old do show an increase in the numbers in education (from 23\% in 2004 to $35 \%$ in 2008; DCFS, 2008). However there should be caution about these figures for three reasons: firstly, the numbers not in education, employment or training have not decreased and remain at about 29\% (about 17,000 young people in this group); secondly, this is a recent trend and many of those aged under 25 will not have been part of it; and finally, research (Dixon, 2008 p. 213) shows that where care leavers are in work and training it is often "casual or temporary employment or low-level, short term training and education courses." Thus there are likely to be a large number of young people in this group who will be in need of support. The level of help that will be offered however will depend on how the government defines 'suitably qualified' as this may be a way of excluding from services some of those who are most needy but unlikely to have formal qualifications.

Research shows that care leavers consistently move to independent living earlier than other young people (Stein 2006) against the general trend where many young people are experiencing extended periods of transition to adulthood with families playing a role in providing financial, practical and emotional support for longer periods of time (Jones 2005). In contrast, those leaving care have to deal with the key elements of transition - managing a home and securing an independent income - over a very short period. This increases the risks for them and makes a successful transition to independent adult life less likely.

In the England and Wales, the Children Leaving Care Act 2000 sought to respond to the problems around transition for young people leaving care by extending the period for which local authorities retained responsibility for care leavers and requiring them to provide a personal advisor and to have a 'pathway plan' for care leavers aged under 21. Additionally, those aged 16 or 17 should be maintained in suitable 
accommodation and provided with financial support while those aged 18 to 20 can be provided with assistance with the costs of education, training and employment. Most Children's Services Departments in England and Wales now incorporate a Care Leavers Service which provides support with accommodation, finances, education and training as well as assisting care leavers to enter employment. Research undertaken since the Leaving Care Act indicates that there has been a shift from more informal interagency links to formal agreements and a key role in taking formal case responsibility is being undertaken by the designated personal advisor (Dixon et al . 2004; Hai \& Williams 2004; Broad 2005). However, Wade et al. (2005). Note that some young asylum seekers are excluded from the provisions of this legislation.

Despite the growing literature on the needs of care leavers there are still relatively few evaluations of programmes aimed at promoting employment opportunities. There are however a number of studies of cohorts of young people leaving care (Allen, 2003; Barn et al., 2005; Dixon et al., 2004). Wade and Dixon's ( 2006) study focuses on what they view as the key ingredients for a successful transition to adulthood housing and employment. They found that 12-15 months after leaving care, the most likely employment status of the young people in their study was being unemployed (44 per cent). Only 23 per cent were engaged in full or part-time education, 6 per cent in training and 8 per cent were caring for a child. They reported that "young people dropped out of education and training placements through financial difficulties, through being placed on courses unsuited to their abilities or interests, through personal or emotional difficulties in their lives or though lack of support and encouragement to maintain motivation" (p.205). These findings are echoed in Allen's (2003) study of a group of care leavers in a rural area and in Barn and colleagues' study (2005) of young people from black and minority groups. These studies suggest that housing may be a greater priority for care leavers than employment and that experience immediately after leaving care exerts a strong effect on the ability of young people to access and sustain involvement in education, training and work.

Wade and Dixon (2006) found some evidence to suggest that targeted career support by professionals was associated with better career outcomes and that the older young people were when leaving care, the more likely they were to be economically active when the researchers recontacted them. Whilst acknowledging current work, the authors highlight the need for early planning which begins well before the point of leaving care and argue for 'a comprehensive package of leaving care support' (p.206) which addresses care leavers’ employment, housing and life skills.

One specific service for care leavers which has been evaluated is mentoring or befriending. For young people about to leave care, mentoring can provide additional and consistent support during transition. Gilligan's study (1999) used case studies to illustrate how mentoring which focussed on cultural and sporting activities could enhance the resilience of children leaving care. Similarly, a small study of one befriending scheme for care leavers in Northern Ireland (McBriar et al 2001) found benefits for care leavers associated with having someone to talk to and help pursue their interests. Clayden and Stein (2005) evaluated fourteen mentoring schemes for care leavers. These projects provided both adult and peer mentoring. The evaluation identified positive outcomes for about half of the young people participating. By the end of the mentoring relationship, achievements by these young people included positive outcomes such as increased confidence and self-esteem, success in 
examinations or gaining independent living skills. Just over three-quarters of them achieved all the goals they had initially set with their mentors. Furthermore, longer mentoring relationships were associated with a greater likelihood of a positive outcome.

Further evidence concerning the value attached to supportive relationships with carers or mentors who have personal experience of the looked after system is provided by Stanley's (2007) study of the mental health needs of looked after children. The young people participating in focus groups for this research highlighted the credibility and authenticity conferred by the experience of having been 'in care'. 'Survivors' of the looked after system can offer those struggling with its legacy positive role models and raise aspirations, as well as offering a realistic appraisal of the challenges which care leavers experience in transition.

Some research has involved care leavers as researchers. The What Makes The Difference (WMTD) project commissioned a peer research study (2007), which involved care leavers in 25 local authorities interviewing 265 care leavers about what made a difference for them whilst in and leaving care. Whilst getting a job was the most common answer to the question about what could make a difference for you in the future, young people also wanted practical, emotional and financial support and some mentioned continuity of support after the age of 21.

Another initiative supported by the WMTD project involved 11 local authorities developing employment and work experience workplans and then meeting regularly with WMTD to discuss progress on implementation. This was then evaluated by young people, practitioners and local authority managers. Key messages from this work were: the need for a dedicated worker to oversee and implement education, training and employment initiatives and support; the requirement for opportunities and support needs to be needs-led and tailored to the individual; and that practical and emotional support for the young people is key to success (WMTD, undated). This finding resonates with Berridge and Beecham's's work (2008) which emphases the importance of relationships with a key worker for improved educational attainment although Harker et al. (2003) found that looked after children considered social workers often failed to take their educational needs into account.

\section{Methodology}

The research, commissioned by the Children's Workforce Development Council, aimed to map the progress of Local Authorities in North West England in providing sustainable employment opportunities for care leavers. The research sought to map plans and actions across the North West region and make recommendations for what was required regionally and locally to ensure the provision of relevant and sustainable employment opportunities for care leavers.

The research utilised an action orientation using a constructivist participatory methodology (Guba and Lincoln, 1989, 2005; Stewart, 1994; Heron and Reason, 1997, Bilson 1997; Bilson and Thorpe 2007). This approach aimed to develop new ways to act by generating new understandings through participating in 'reflexive conversations' (for a full outline of this approach see Bilson, 1997). In this way the 
research process is one of engagement rather than detached observation. However, this methodology uses formal research methods such as surveys and interviews within this framework in this case including:.

a) Review of employment schemes for care leavers

Searches of the web and journals were used to identify examples of approaches to employment opportunities for care leavers across England. In a number of cases those responsible for the schemes were contacted to gather information and this snowballing yielded further examples of schemes.

b) Survey of local authorities in North West Region

This was undertaken through telephone interviews using a semi-structured interview schedule with six stakeholders representing five different authorities in one regional partnership. A questionnaire was distributed by email to key contacts nominated by the children's workforce leaders in all local authorities in the region. The survey aimed to discover the extent of local provision for employment of care leavers as well as strategy, plans and the degree of interagency work. Follow-up telephone calls resulted in 18 of the 22 authorities completing the survey, a response rate of 82 per cent.

c) Workshops

Three half day workshops for workforce leads and partners were held across the region. These workshops presented the interim findings from the earlier stages of the research and gathered information on what was needed at local and regional level to promote employment opportunities for care leavers. Researchers participated in the groupwork and the final feedback was videotaped and analysed.

The views of young people were not sought as part of the research but a later consultation with a group of care leavers provides some indications about the research and its recommendations which will be discussed in the findings below.

\section{Findings}

A range of schemes promoting employment opportunities for care leavers and other excluded young people was identified both within the North West Region and across England; details of these schemes are included in the project report (Authors' own, 2008). Analysis of the data collected on schemes found that they usually involved one or more of the elements shown in Box 1.

The different models identified suggest that a range of responses to supporting the training and employment needs of looked after children and young people have developed reflecting the emerging understanding that the varied support required by young people in transition needs to be holistic in its approach (ODPM, 2005). However, as noted above, the evidence for the effectiveness of these different approaches is limited: few of these initiatives had been evaluated.

The survey and regional workshops identified a number of issues and areas for development which are outlined below.

Need for strategic planning for a comprehensive service 


\section{Box 1 Key Elements of Employment Schemes}

1. Preparation for employment /employability schemes These focused on improving basic skills, enhancing personal development and promoting a realistic understanding of what would be expected in the work environment.

\section{Work experience schemes}

These schemes involved looked after children at secondary school or care leavers post 16 undertaking usually unpaid work for a short of time in order to gain experience in the workplace.

\section{Work placements/traineeships}

These enabled participants without qualifications and at any level of ability to gain longer periods of experience in the workplace and usually also to study for a recognised qualification.

\section{Apprenticeships}

Apprenticeships focused on training on the job for three years alongside studying for an NVQ Level Two or Three. Unlike normal apprenticeship schemes, schemes for care leavers often had no entry criteria - applicants did not need to have any qualifications, however, the potential to achieve NVQ Level 2 was required.

\section{Mentoring}

These involved older care leavers engaged in education, training or employment in mentoring younger looked after children and care leavers. This support was delivered face-to-face or via email (e-mentoring). The mentors acted as positive role models, supporting and encouraging looked after children and young people to achieve at school and in employment settings and to consider their future career options.

Nine out of twenty local authorities reported that they had a policy, strategy or plan related to employment opportunities for care eavers. Others said a plan was being developed and, even where there was no plan, there was usually a service in place or being developed. However, eleven authorities had no formal policy or strategy and there were no examples of a comprehensive range of services designed to meet the needs of all relevant care leavers. This led to comments such as the following from one group in its feedback at the regional workshops: "there isn't a complete coherence to what we are seeking to do in terms of employment." Thus there is need for a more comprehensive planning system. This was echoed in the comments of the young people one of whom said with disdain "Social services have plans for everything else, so why not this?"

\section{Resources}

The reliance on short-term funding for schemes was a theme which emerged throughout the research. It was emphasised that authorities had now reached a point where mainstream funding was needed and the need for schemes to be 'permanent' was also felt to be important by care leavers. Several groups discussed the 'spend to 
save' notion as a way of pushing forward the agenda and meeting employment needs. A number of groups also suggested that investing in looked after children and young people at an early age was key and those participating in the regional workshops argued that such investment would reduce the need for provision in other sectors:

"You can see the potential big benefits of saving the costs of the statistics that we arrange around imprisonment, homelessness and mental health. It is staring us in the face but where do you deliver up the money and convince people that the spend of money in the short-term will be of benefit later on."

It was recognised that new funding was unlikely to be available and workshop participants identified the need to make better use of existing resources and to recycle funding:

"We looked at money and we realised that there is a lot of money around but that it is tied up in existing care costs but there is massive amounts of money. We also looked at the range of opportunities that might be around in terms of pooling or sharing or starting to recycle money and that might realistically be the way forward"

Arrangements for sharing budgets to be used to fund employment opportunities were seen as an area where further progress was required. Workshop participants noted that, despite the government's commitment to joined-up arrangements for children, separate budgets for departments and services created barriers to the development of new initiatives:

"If you are with the Leaving Care Team you don't have the Youth Justice budget and the Youth Justice doesn't hold the budget for the Young Offenders centres. It is how you bring that together."

The lack of an evidence base for the effectiveness of initiatives was cited as another barrier to accessing funding. Developing knowledge about where and how to identify and access funds to support employment schemes was seen as vital.

\section{Inter-agency collaboration}

Inter-agency collaboration and inter-agency working were identified as crucial elements in providing employment opportunities. The involvement of a wide range of different services was required to ensure that the complex support needs of looked after young people were met. There was concern that the issue of employment opportunities was seen exclusively as a task for leaving care teams and one survey respondent noted the need: "to make sure this is a wider agenda than Children's Services". One workshop group suggested that the employability sector needed to collaborate more closely with leaving care teams and that concepts and language needed to be shared - a finding which echoes the recommendations of the Scottish Executive study (2005) on employability services for disengaged young people.

The configuration of organisations required to contribute to initiatives was thought to be very complex. One group participating in the regional workshops reported that "just in one authority we listed 9 or 10 [organisations] that we need to pull together". The organisations identified as needing to collaborate on planning and 
delivery of initiatives included: children's services, further and higher education, adult social care, young offender teams, a range of health services, learning and skills councils, Connexions, voluntary organisations, housing agencies, welfare benefit organisations as well as local and regional employers. Achieving sign-up from a wide range of partners was considered to be one of the functions of children's trusts.

New approaches to support for looked after young people

Early intervention that flagged up the issue of employment and aimed to raise career aspirations among looked after children was seen as important. One regional workshop group suggested that job preparation should begin in Year Seven at school. This was seen as a task that Virtual Schools for looked after children and young people (a new initiative providing a body to overview the education of looked after children throughout an area) could take on:

"I think the trick is to use the Virtual Schools now to get into Years 9, 10 and 11, to be working with those kids, identifying what the issues are and getting them introduced more rapidly to the services that can assist them with the employment and accommodation as well."

Many care leavers do not live in the local authority area responsible for funding services for them and this requires effective arrangements to allow them access to provision where they live. There was some discussion in the regional workshops about "our" children (those who are the responsibility of this local authority) and "their" children (children placed from outside) with the view that "our" children would get preferential treatment. Provision for looked after children's health and education is legally the responsibility of the local authority where they are placed but services for care leavers, including preparation for employment, are the responsibility of the placing authority. This could make some groups of children second class citizens in terms of accessing support and services.

Another key issue identified in the workshops was the transition from children's to adult services. This is acknowledged as a period of high risk for vulnerable young people (ODPM, 2005) and the problems posed by changes of workers which looked after young people experienced at the age of 15-16 and again at 18 were discussed in all the regional workshops. Participants suggested that a greater synergy was needed between children's and adults' services. One group argued that the transition from children's to adult services was a response to the bureaucratic needs of the agencies rather than those of children:

"We have to challenge our preconceptions about who should maintain that longer-term relationship with them."

The issue of continuity of support was discussed in the workshops and it was recognised that maintaining young people's key relationships could contribute to their success in training and employment. It was suggested that it would be more effective to have one identified practitioner to co-ordinate all the support for each young person. It was also noted that the entry into full employment can be an extended process and the need to maintain support for looked after children and young people seeking employment over time was emphasised: 
"We need to long-term track people to mid-twenties... in terms of knowing what actually happens to young people in the long-term. We only see a snapshot and deal with issues as they arise"

A key issue faced in delivering employment schemes was the need to address the support needs of participants in the work setting. These could be extensive and embrace issues such as accommodation, life skills, literacy, job specific training and 'ready for work' skills. One workshop participant reported that a previous scheme had failed as there was "a greater focus on finding placements than putting in the support". Survey respondents stressed that young care leavers needed to be supported "to develop key skills" and "trained workplace mentors are essential". The provision of support in the workplace was considered to be essential:

"Finding employers who are willing to take on the additional pastoral care role...Finding work placement supervisors who have the time and/or training to offer the pastoral support".

(Survey respondent)

Employers who had developed an understanding of "the background and needs of young people" were described as more likely to "stick with them" when problems arose. For example, young people might need additional support "to accommodate the discipline required of a work placement". Survey respondents suggested that if employers were to be able to appreciate these difficulties, "slow development" was needed "to allow placement providers to understand the care system and its complexities".

Young people participating in the consultation expressed concerns about the need for a wage that would cover their living expenses, some feeling that low wage levels and the cost of fuel bills and accommodation meant that there was little incentive to work.

\section{Regional and local action}

Action was needed at the local level "to get our own house in order" (workshop participant). Workshop participants felt that the job of promoting and developing employment opportunities was often the responsibility of several people and they commented that development was slow because "people are busy doing their day job”. It was felt there was the need for a dedicated coordinator for looked after children and young people employment at the local level. However, in another workshop it was suggested that for smaller authorities, sub-regional collaboration might be a more appropriate strategy:

"I am not sure we would actually have the volume to keep somebody full-time engaged in this so we would have to give them something else to do and then they wouldn't dedicate, etc. So we feel that there is real mileage in small clusters or pairs of authorities sharing that resource."

The role envisaged for such a coordinator would not be confined to developing work opportunities but also to link across agencies, and to deal with legal and contractual issues such as terms and conditions of service. 
Workshop participants suggested that regional government responsibilities might include providing guidance on certain 'sticky' problems. This might include guidelines for a pay structure; mechanisms to engage major contractors and developers in providing employment opportunities; and advice on dealing with issues of equal opportunities amongst much else:

"What we felt we would like to get out of the region was a single model or a single template that would cover not just pay but learning and development."

Another idea developed in the workshops was the potential for a regional scheme to assume a brokerage role with large private sector employers and trade unions in the North West:

"We need to look at our relationships at executive level with the private sector, particularly with the major employers."

Workshop participants also identified scope to build arrangements for work placements for care leavers into local authorities' service contracts (although there were some concerns around the legality of this), and it was noted that this approach might be promoted through "some sort of regional steering on that to Chief Executives in the departments". This approach was also mentioned as relevant for local authorities' relationships with the third sector. One group felt that the third sector were well-equipped to support care leavers in work placements and it was suggested that such work opportunities could be built into service contracts with these organisations.

\section{Targeted schemes and ring-fenced opportunities}

Whilst the benefits of inclusion were recognised, positive discrimination or ringfencing was discussed in all the workshops as a way of ensuring that looked after children and young people were provided with sufficient high quality opportunities. Ring-fencing also emerged as a key theme in the survey data. One regional workshop group described the effects of expanding a scheme to include a wider group of young people. This had resulted in looked after young people 'losing out' in the competition for opportunities:

"because they are from a different starting point so they are so far down the pecking order that they are not actually getting a look in at the employment opportunities that are being found".

However, for some smaller authorities, prioritising are leavers within a scheme focused on a wider group of young people appeared to be a more feasible approach. The young people consulted did not want to have schemes specific to care leavers although they did want to have reserved places and recognised that some young care leavers had special needs and might require extra support.

One North-West scheme was in the process of developing an Integrated Children's Services Worker Apprenticeship. Proponents of this scheme likened it to recruiting young people into the 'family business'. However, employment opportunities with a high education and training component may not be pitched at the appropriate level for 
most looked young people, nor should it be assumed that they all will want to enter care work: the young people participating in the consultation were enthusiastic about such opportunities although they also noted that looked after young people have differing abilities and needs. Two workshops discussed providing apprenticeship opportunities in the children's workforce where the young person was supernumerary to the required staffing levels. This would enable organisations providing placements to manage issues such as unplanned absences or lateness for work more easily. A participant explained that this approach had proved constructive in placing young people in early years settings:

"in terms of staffing ratios it is really important to early years that these kids don't go in and become part of the staffing ratio because if that's not working then all of a sudden then we don't want these children on placement as they are a risk to us" (Workshop One)

\section{Limited Information}

Workshop participants agreed that the information available on the numbers and needs of those who might require services is limited. Much of what is available uses the information drawn from statistical returns. In particular there is little use being made for service planning of information from individual plans and assessments. Whilst there was some evidence of consultation with looked after children there was still little information available concerning their needs and desires, particularly those of young people who have already left care.

There was also a need to share information on service developments between agencies to prevent "reinventing the wheel" (the research report provides details of schemes it identified; Authors' own 2008)

\section{Discussion}

Much remains to be done in developing support systems and services to assist looked after young people into employment. A strong focus on the educational achievement of looked after children may have, until recently, obscured the need to develop employment support. The research suggested that emphasising the corporate parenting role of local authorities was one way in which Children's Services could be alerted to the need to develop services that aimed to prepare a young person for employment. Identifying the long term social costs of failing to offer looked after young people such services was considered to be another means by which the value of such development could be highlighted.

The review of employment schemes for care leavers identified a number of models that children's services can draw on in building their services although the evidence concerning the effectiveness of various approaches is as yet limited. However, key features of any such service identified by this research include the collaboration of a range of different organisations to develop employment and training packages coordinated by a single identified person who can offer continuity to young care leavers. The need for an early start to planning employment and training for looked after children and young people was also emphasised and there may be a role in respect to this for the Virtual Schools currently being piloted in England. The regional 
workshops included in this study also identified opportunities for collaboration in the development and provision of training and employment opportunities between local authorities. A role was envisaged for regional bodies in providing support in the form of guidance as well as promoting trans-regional initiatives with employers and training providers.

The study also identified some contentious issues which need to be explored in further studies. These include the question of whether ring-fencing training or employment opportunities for looked after children acts to include or exclude them and whether providing looked after young people with opportunities for training and employment in care work restricts their options or offers them a chance to enter a field of employment in which they have already gained expertise as service users.

\section{Conclusion}

Young people who have been looked after are particularly at risk of becoming socially excluded. For a significant proportion of them, their experiences in their birth families are at best not ameliorated by the care they receive from their statutory parents. Many leave care to become isolated, unemployed and to experience a range of other problems. The study was supported by a working group including staff from Regional Government, Children's Workforce Development Council, Skills for Care, and a range of agencies. This group organised a conference to disseminate the study findings and has been instrumental in accessing funding for a regional coordinator's post and a pledge from 16 of the 22 local authorities in the North West to implement all of the recommendations of the study. Considerable enthusiasm has been generated in the region for partnership working focused on developing training and employment opportunities for care leavers. At a national level, the government has promised apprenticeships to all "suitably qualified" care-leavers aged under 24. If care leavers are to benefit from this provision, the level of qualification for apprenticeships will need to be set at a point that does not exclude those whose educational attainment on leaving care was low; it is these young people who need most support in entering the world of work. 


\section{References}

Allen M, (2003) Into the mainstream: care leavers entering work, education and training York: Joseph Rowntree Foundation

Berridge D and Beecham J. (2008) Educating Difficult Adolescents: An Evaluation Of 'Quality Protects': Research Brief London, DCSF

Bilson A. (1997) "Guidelines for a Constructivist Approach: Steps Towards the Adaptation of Ideas from Family Therapy for Use in Organizations" Systems Practice, $10,2,153-178$

Bilson A and Thorpe D (2007) Towards aesthetic seduction using emotional engagement and stories. Kybernetics 36, 7/8, 936-945.

DCSF (2008) Statistical First Release 2007-2008: Statistical First Release 2007-2008 Trends - Children looked after at 31 March accessed on 27/01/2008 from http://www.dcsf.gov.uk/rsgateway/DB/SFR/s000810/SFRcontentsdec.xls

DFES (2003) Statistics of Education: Care Leavers, 2002-2003, England accessed on $27 / 01 / 2008$ from http://www.dcsf.gov.uk/rsgateway/DB/SBU/b000423/stats_bulletin_05_03.pdf

DH (2002) Care leavers, year ending 31 March 2002, England accessed on 27/01/2008 from http://www.dh.gov.uk/en/Publicationsandstatistics/Statistics/StatisticalWorkAreas/Sta $\underline{\text { tisticalsocialcare/DH_ } 4000240}$

DH (2001) Educational qualifications of care leavers, year ending 31 March 2001: England accessed on 27/01/2008 from http://www.dh.gov.uk/en/Publicationsandstatistics/Statistics/StatisticalWorkAreas/Sta $\underline{\text { tisticalsocialcare/DH_4016079 }}$

Dixon J. (2008) "Young people leaving care: health, well-being and outcomes" Child and Family Social Work 13, pp 207-217.

Dixon , J., Lee, J., Wade, J., Byford, S. and Weatherly, H. (2004) Young people leaving care: A study of costs and outcomes. Final Report to the Department of Health. London: Department of Health

Guba, E.G. and Lincoln, Y.S. (1989). Fourth Generation Evaluation. Sydney: Sage.

Guba, E.G. and Lincoln, Y.S. (2005). Paradigmatic Controversies, Contradictions and Emerging Confluences emerging confluences In N. K. Denzin \& Y. S. Lincoln (eds.) Sage handbook of qualitative research. Thousand Oaks, CA: Sage.

HM Government (2009) New Opportunities: Fair Chances for the Future Norwich, TSO

Heron, J., \& Reason, P. (1997). “A Participatory Inquiry Paradigm” Qualitative Inquiry, 3,3, 274-294. 
Jones, G. (2005). The thinking and behaviour of young adults (aged 16-25):

Literature review for the Social Exclusion Unit. London: Office of the Deputy Prime Minister.

Ofsted (2008) The Annual Report of Her Majesty’s Chief Inspector of Education,

Office of the Deputy Prime Minister (2005) Transitions: Young Adults with Complex Needs, A Social Exclusion Unit Final Report. Wetherby: ODPM Publications.

Scottish Executive Social Research (2005) Mapping Employability and Support Services for Disengaged Young People Edinburgh: Scottish Executive Social Research Accessed on $16^{\text {th }}$ June from http://www.scotland.gov.uk/Resource/Doc/77843/0018813.pdf

Social Exclusion Unit. (2002). Reducing re-offending by ex-prisoners London: Office of the Deputy Prime Minister

Stanley, N. (2007) 'Young People’s and Carers' Perspectives on the Mental Health Needs of Looked After Adolescents’. Child and Family Social Work, 12, 258-67.

Stein M (2006) "Research Review: Young people leaving care” Child and Family Social Work 11, 273-279.

Stewart, A. (1994) “Constructivism and Collaborative Enterprises” in L. Fell, D. Russell \& A. Stewart (eds) Seized by Agreement, Swamped by Understanding Sydney: Hawkesbury.

Wade, J. and Dixon, J. (2006). Making a home, finding a job: investigating early housing and employment outcomes for young people leaving care. Child and Family Social Work, 11, 199-208.

WMTD (2007) What Makes the Difference? Peer Research Report WMTD/Rainer and NCB accessed on $18^{\text {th }}$ June 2008 from http://www.leavingcare.org/data/tmp/3972-8238.pdf 

